\title{
4 Europeanization of renewables support
}

\author{
Elin Lerum Boasson
}

\section{Introduction}

This chapter chronicles how the European environment of support to renewable electricity has developed and changed over the course of four decades. In some countries, promotion of new renewable energy began as a domestic policy issue in the 1970s. With the rise of attention to the climate issue in the 1990s, support schemes became a widespread policy measure, eventually becoming subject to significant EU steering.

For a long period, technology-specific feed-in schemes dominated in Europe. These offered beneficiaries a fixed price for electricity for 15 to 20 years, independent of market-price fluctations, often ensuring different levels of support for different renewables technologies (Cointe and Nadaï 2018). To the surprise of many, in 2014 the EU adopted state-aid guidelines that steered countries towards shifting to competitive auctioning combined with feed-in premiums (support on top of the spot-market electricity price; see Fitch-Roy et al. 2019). This shift was not the result of changes in EU renewables policy proper, but of the introduction of new guidelines on state aid for environmental protection and energy.

The European environment is a meta-field, embracing developments at the allEU level as well as in the member states. It can be described along two dimensions (Boasson 2021, Chapter 3 in this book). The horizontal dimension captures how the countries interact and influence each other, while the vertical dimension captures how EU actors and processes interrelate with actors and developments at the domestic level. This chapter asks: How has the European environment changed over time with respect to the horizontal as well as vertical dimensions of Europeanization?

Two strands of EU policies are relevant to developments in support schemes for renewables: EU renewables policy proper, as set out in the Renewables Directives, and the EU rules on state aid. The EU started to develop a renewable energy policy already in the 1970s, but the 2001 Renewable Electricity Directive was the first piece of legislation with relevance for national support measures (Boasson and Wettestad 2013). In 2001, the EU also for the first time developed guidelines on state aid for environmental protection that included renewable energy. Later, 
these two strands of policies have changed. The member states have developed various practices in renewable energy schemes, sometimes in response to developments at the EU level, other times as a precondition for EU-level change, and sometimes rather isolated from activities at the EU level. The six case studies, presented in Part II of this book, explore in detail how and to what extent the European environment has played into these domestic processes.

Most assessments of EU renewables policy have focused on renewables policy proper (e.g., Boasson and Wettestad 2013; Bürgin 2015; Cointe and Nadaï 2018; Solorio and Jörgens 2017). This is an interesting issue-area in itself - but, when the focus is on renewables support schemes, we also need to explore the development of EU state-aid policy. Indeed, it is not possible to understand the major revisions of support schemes for renewables in many EU member states after 2010 without taking into account the changes in EU state-aid guidelines in 2014.

Whereas the development of EU renewables policy follows ordinary legislative procedures (formerly called co-decision), the European Commission (the Commission) has the upper hand in revising state-aid guidelines. In the ordinary decision procedure, the Commission presents a draft, the Council and the Parliament put forward amendments and, finally, the Parliament and the Council jointly adopt a decision. In contrast, the adoption of new state-aid guidelines is the prerogative of the EU executive - the College of Commissioners (Büthe 2016). The Commission's Directorate-General for Energy (DG Energy) drafts renewables policy proposals, while the Directorate-General for Competition (DG Competition) drafts state-aid guidelines. ${ }^{1}$ It has been argued that the Commission has increasingly used stateaid rules as its last resort to steer national developments (Blauberger 2009; Smith 1998). As a main rule, the EU prohibits state aid, but under certain conditions, it may be accepted (Büthe 2016; Smith 1998). EU state-aid rules are inherently political: they involve choosing between competing political objectives, and the decision outcomes constrain the powers of national governments (Büthe 2016: 38; Kassim and Lyons 2013).

Such guidelines draw on the Treaty and CJEU case law, presenting principles for assessing the compatibility of aid (Banet 2020). They are interpretations of the state-aid rules in the basic Treaty on the Functioning of the EU (TFEU) (Art. 7, Art. 87 TEC) as well as case law from the Commission's DG Competition and Court of Justice of the EU (CJEU). The guidelines are not legally binding on member states, but they are binding on the Commission. Member states may challenge the guidelines, but this may entail long delays, affecting renewables investments while litigation drags on. Hence, the exact wording of the state-aid guidelines can be of crucial importance for the development of national practices.

This chapter presents the chronological story of renewables policy developments in the European environment, starting with the rather long and slow emergence of this policy area from the 1970s until 1999, then moving on to the first five-year period with some EU steering of significance, from 2000 to 2004. Next we turn to the 2005-2009 period, with major conflicts at both the EU level and in many member states, and finish with the period from 2010 to 2014 . $^{2}$ 


\section{Renewables support: From rare and national to widespread and EU-governed}

\section{Prior to 1999: many ideas, little harmonization}

From the 1970s and onwards, there was considerable trial and error, with differing countries adopting varying schemes, although primarily small in scope and simple in design (Boasson and Wettestad 2013; Solorio and Jörgens 2017). During this period, a group of academics also developed differing ideas about more encompassing support schemes. Still, renewable energy was only a marginal policy issue, with few actors wanting the EU to gain the upper hand.

By the early 1990s, three different domestic renewables strategies had emerged. First, Germany, Denmark and, eventually, Spain embarked on technology-specific schemes that involved very little exposure to market forces (Boasson and Wettestad 2013: 82-83). They launched feed-in schemes, relying on fixed support levels for rather long time-periods and guaranteed grid access. These schemes led to the emergence of small-scale domestic renewable-energy industries. The second group of countries - Finland, the Netherlands, Sweden and the UK - offered R\&D support and some other measures but did not develop feed-in schemes. In these countries, the traditional utilities initiated a few renewable energy plants, but no new renewables industries emerged. The third and largest group of EU countries hardly promoted renewables at all.

In 1988, the Commission considered harmonizing renewables support, but this came to nothing (Rusche 2015: 25). The first renewables schemes were notified to the Commission in 1990; DG Competition found that both the British and the German schemes constituted state aid but swiftly approved both (Rusche 2015: 81-82). A little later, DG Competition endorsed schemes in the Netherlands, Sweden, Finland and Denmark (ibid.: 82). In order to be regarded as state aid, renewables aid must: (1) be granted by a member state or through state resources in some form, (2) distort or threaten to distort competition, (3) selectively favour certain undertakings and (4) affect trade between member states in a way incompatible with the internal market (Community Guidelines 2008, Art. 7.1). Renewables aid that fulfils these criteria can still be exempted from the ban on state aid if the aid promotes 'the execution of an important project of common European interest' (Community Guidelines 2008, Art. 7.2). At this stage, EU steering attracted scant public attention. In the course of the 1990s, EU authority within the realm of state aid became contested, with respect to renewables support as well as a range of other issues (Büthe 2016: 39).

Germany subsequently changed its scheme, and the German Utilities Association lodged a complaint with the Commission over application of the state-aid rules (Jacobsson and Lauber 2006). In response, DG Competition sent a letter to the German government expressing doubt about the continued compatibility with state-aid rules and proposing amendments that would bring German law in line with EU state-aid rules, leading to a reduction in feed-in rates (CJEU 2000, Art. 19-21). In 1998, Germany introduced a revised scheme but, despite consultations 
with DG Competition, did not follow up any of the proposals from the Commission (CJEU 2000, Art. 34-38). Instead, it decided that the distribution system operators could pass on their additional economic burden from buying electricity from renewables to the transmission system operators. Although CG Comp complained about this to Germany, it refrained from asking Germany to notify, because a new Renewables Directive was expected to introduce harmonized renewables rules.

At this stage, the electricity supplier PreussenElektra AG refused to pay the distribution system operator Schleswag the extra costs incurred in buying renewables electricity required by the German feed-in law (Kuhn 2001; Rusche 2015: 38). The issue was brought before a German court, which eventually requested the CJEU to clarify whether PreussenElektra was correct in arguing that the German scheme fell under the Treaty's definition of state aid (CJEU 2000, 2001). In the two years that passed before the CJEU reached a judgement, a major political controversy emerged over EU steering of renewables aid in a new renewable electricity directive (CJEU 2000, Art. 38).

DG Energy argued that national support schemes were no longer compatible with state-aid rules. It proposed creating a technology-neutral pan-European 'renewable energy credit' scheme, which would expose renewables to market prices on electricity, and began drafting a directive to that end (Boasson and Wettestad 2013: 84, 87; Rusche 2015: 30). Whereas the largest European electricity utilities supported the idea, the renewable energy industry mobilized against it (Boasson and Wettestad 2013: 84-85). Both industries had ties to Commission officials who supported their opposing views, and major conflicts erupted between the camps. The high level of conflict created uncertainty as to whether the EU would be able to develop a renewables policy of any significance.

The German government protested vigorously against the Commission's initiative for a Renewables Directive, but the Netherlands, Sweden and the UK were more positive. At the national level, the market idea got off to a rather bad start: the British quota system failed to yield much production, and the Dutch government abandoned its voluntary certificate scheme soon after its introduction (Boasson and Wettestad 2013: 85-86). In the end, the EU energy ministers agreed that the Commission should develop a Renewables Directive, on the condition that it did not aim to steer the national support schemes. In parallel, DG Competition began more actively reviewing member states' state-aid practices in a range of issue-areas (Büthe 2016: 56-58). Despite the lack of political consensus in the Council with respect to renewables support, many Commission officials continued to promote a pan-European scheme, based on a certificate scheme idea (Boasson and Wettestad 2013: 83-87).

By the late 1990s, the Court had largely confirmed that the Treaty gave the Commission substantial authority over state aid, but it was unclear whether most renewables schemes fell under the Treaty's definition of state aid (Büthe 2016: 56-58). The Commission had gained authority to require recipients of unlawful aid to repay aid, but many years would pass before it became clear whether the Commission could apply this authority to renewables schemes. 
We may conclude that by the late 1990s, the Europeanization process had barely started. Vertical steering was weak, with no clear horizontal patterns discernible. Rather, the few countries that had adopted renewables support schemes drew primarily on their own domestic traditions and experiences, rarely looking to others for inspiration and learning. For most of this period, the EU had relatively few members, and it was unclear whether the EU would be able to exert any governance at all with respect to renewables support.

\section{0-2004: much EU conflicts, but feed-in diffuses}

Around 2000, renewables support became increasingly salient at the EU level. The Commission's understanding of how and to what extent it could influence national renewables support was also fundamentally challenged during this period. In the midst of heated discussions on the Renewables Directive, the Advocate General of the CJEU in 2000 issued an opinion in the PreussenElektra case, concluding that the changes that Germany had introduced to its feed-in law in 1998 were not sufficient to trigger the need for new notification - moreover, that the scheme did not constitute state aid (CJEU 2000, Art. 19; Kuhn 2001). As neither PreussenElektra nor Schleswag was publicly owned, the money never actually passed through the state or through state resources, and thus the German scheme could not be regarded as 'state' aid (Rusche 2015:. 83). This intervention came as a great surprise to DG Energy, DG Competition and DG Legal Service, who had all defended the Commission's view in the court case (Interviews 5, 6 and 8).

In 2001, the CJEU reached a decision, largely in line with the opinion of its Advocate General (CJEU 2001). By then, however, Germany had changed its system, introducing technology-specific support levels guaranteed for 20 years (CJEU 2000, Art. 34-38; Cointe and Nadaï 2018: 6, 61). It did not notify the Commission, nor did France when it adopted a similar scheme, although the French scheme did repay utilities by means of state resources (CJEU 2013; Rusche 2015).

Many struggled to interpret the precedence created by PreussenElektra. Did the ruling imply that neither the Commission nor the CJEU could overrule national renewables support schemes? Or was the German case so special that it did not really create precedence (Kuhn 2001: 364; Rusche 2015: 85)? Interviewees familiar with this case regard it as highly significant. One interviewee (6) stated: 'It is amazing how much this [PreussenElektra] influenced the understanding of state aid'. DG Competition officials were confused, leading their decisions in the immediate aftermath of the judgement to lack consistency (Rusche 2015: 86). In any event, the Court's decision legitimized a swift diffusion of feed-in schemes (Cointe and Nadaï 2018: 63).

In 2000, DG Energy published a draft Renewables Directive, proposing a deadline for EU-wide harmonization of support schemes. However, the deadline idea failed to gain support from the Parliament and the Energy Council. The Renewable Electricity Directive was adopted in September 2001 but made no references to market streamlining or harmonization (Directive 2001/77/EC). The same year, DG Competition launched the first state-aid guidelines in which renewable energy 
was included. These guidelines did not promote market streamlining or harmonization (Community Guidelines 2001). They distinguished between how investment support and operational support could be calculated, but they introduced no clear limitations on how much aid a renewables plant could receive over its lifetime. Calculations of investment support were to be based on the 'extra costs' compared to conventional plants. It was made clear that operating aid would 'usually be allowable'; and different design options were presented: (a) the 'extra-cost' approach, providing aid 'to compensate for the difference between the production cost of renewable energy and the market price', and (b) the application of 'market mechanisms such as green certificates or tenders' (Community Guidelines, Articles E.3.3.2 and E.3.3.3).

In the following years, the countries that first adopted feed-in schemes stayed on their original path and many others copied them, making feed-in the most widespread way of promoting renewables. Most notably, both Spain and France adopted schemes inspired by Germany and Denmark (Boasson and Wettestad 2013: 86-87; Leiren and Reimer 2021, this book). A few countries opted for green certificate schemes; for instance, Sweden adopted a scheme that immediately boosted renewables investment (Boasson, Faber and Bäckstrand 2021). Still, by 2005 the academic literature as well as most DG Energy documents concluded that feed-in schemes were more effective and less costly than electricity certificates (Cointe and Nadaï 2018: 72).

Hence, the 2000-2004 period was marked by horizontal harmonization: Feedin diffused among the EU member states - but this was not a result of vertical, topdown steering from the EU, but rather a result of horizontal socialization across countries. Despite the Commission's campaign for technology-neutral certificate schemes, it was the technology-specific feed-in model that gained popularity. At this stage, it was still usual to have only one or a few support schemes, but from 2005 and onwards, the support-scheme mixes became increasingly complex.

\section{5-2009: intensified feed-in diffusion and binding renewables targets}

In this period, climate change became a high-level political issue. No longer discussed only by environmental and energy ministers, it became a key point of interest for prime ministers and an important issue in many general elections across Europe (Boasson and Wettestad 2013: 87-94). Moreover, climate change climbed to the top of the agenda as the EU prepared for the global climate summit in Copenhagen in 2009. The conflict from a few years back, between technologyneutral and technology-specific approaches to renewables support, resurfaced. A significant renewables industry had emerged, with strong ties to parts of DG Energy and the European Parliament. Renewables promoters were united in their scepticism towards market streamlining and EU-level harmonization.

By this stage, only seven EU member states had green certificates, whereas 18 had feed-in schemes (Commission 2008a). While many in DG Energy were pleased with the diffusion of feed-in schemes, other Commission officials set 
about floating a new version of the old idea of a pan-European electricity certificate scheme (Boasson and Wettestad 2013: 87-94). They envisaged a scheme where aid would be granted to the least costly renewables projects, market forces would determine the support levels and governments would no longer be able to favour specific technologies. The renewables industry, as well as German and Spanish ministries, criticized the idea. The tone was harsh; actors accused each other of fraud, lack of credibility and being reactionary.

DG Energy officials opposed to the market approach ensured that the draft directive was 'leaked' in December 2007 (Boasson and Wettestad 2013: 91), only weeks before the Commission was to launch the draft. The renewables community had little time to lobby against the draft, but it largely succeeded. One month later, in January, the Commission issued a new and rather inconsistent draft directive, opening up for certificate trading but without measures that would ensure the creation of a pan-European certificate scheme (Commission 2008b). At the same time, DG Competition launched revised state-aid guidelines. The 2008 guidelines were quite similar to the 2001 version and were not aligned with the draft directive. They did, however, give more weight to incentivizing lower support levels (Community Guidelines 2008, Art. 1.3.5). One interviewee (2) from DG Energy held that the state-aid revision was not strongly coordinated with the Renewables Directive revision, whereas an interviewee (5) from DG Legal Service stated: 'When they suggested developing a directive at the same time, it would be too blatant if they simultaneously included it in the guidelines. This was due to political considerations'. A DG Competition interviewee explained: 'nobody cared about state-aid guidelines in 2008 . It is only more recently that it has attracted a lot of interest'.

At around the same time, the Court radically changed its interpretation of the Treaty. First, the CJEU Advocate General issued an opinion in January 2008 in the Essent Netwerk Noord $B V$ case, on state aid in the electricity sector in general. Here, the Advocate General argued that the PreussenElektra case was very special: the feed-in costs were not transferred through state resources, and no public entities or private entities created by the government were involved, but this was rare. Hence, the case had little general value for how state-aid rules should be understood (CJEU 2008; Rusche 2015: 103-104). The Court upheld this view in July (Mortensen 2008). According to two interviewees (5, 6), DG Competition had long wanted to challenge PreussenElektra, and the Essent Netwerk Noord BV paved the way for this.

Revision of the Renewables Directive was subject to fierce debate throughout 2008. An increasing number of voices now raised the concern that many feed-in schemes provided over-compensation for renewables (Cointe and Nadaï 2018: 90). One Commission interviewee even stated: 'We had a lot of people we had never seen before coming to us in black limousines. We understood then that something was wrong' (Interview 8). This hardly influenced the political deliberations, however. A major breakthrough for the strategy of the renewables actors came with the joint compromise proposal from the UK, Poland and Germany in June 2008 (Boasson and Wettestad 2013: 92). The proposal ensured member 
states' control over their national support schemes. In the end, the Council and the Parliament adopted a directive that contained binding national renewables targets and required member states to continue to offer state aid to renewables, but they did not give the Commission new authority over domestic support-scheme designs (Directive 2018/2001). As noted, a new CJEU ruling enabled the DG Competition to start applying its state-aid powers on renewables support, but few energy actors seem to have noticed this significant shift in CJEU case law. Smallscale and costly renewables technology gained increased interest, with many countries introducing special feed-in rules for these specific technologies or other types of special support schemes (see the following chapters in this book: Rayner et al. 2021; Leiren and Reimer 2021; Boasson, Banet and Wettestad 2021).

In the end, whereas the adoption of new, domestic renewables targets created indirect pressure on member states to offer more support to renewables support, the EU did not give any clear instructions on how member states should alter their existing support mixes. Any indirect vertical Europeanization was rather diffuse and gave domestic actors considerable room for interpretation. At the domestic level, the horizontal diffusion of feed-in schemes continued, in tandem with renewed interest in small-scale and costly technologies. The financial crisis that hit Europe after 2008, and the fact that many countries had schemes that over-compensated renewables investors, contributed to changing the dynamics of developments in the domestic renewables support mix. In this period, ideological conflicts hindered fruitful dialogue between new renewables actors and traditional energy actors. However, as we will see, such disagreements gradually became less severe.

\section{0-2016: shift to new support-scheme model and increased state-aid steering}

The economic crisis constrained the ability of many member states to offer renewables support, and the costs of renewables costs had become dramatically lower. This led many to reconsider their views on renewables support schemes (Cointe and Nadaï 2018: 89-90). The debate now shifted from a trench war to a more nuanced, though still sometimes heated, exchange of information and ideas (ibid.: 95).

The introduction of a significant share of intermittent renewables changed the price-setting mechanisms in European electricity markets, largely to the disadvantage of the large utilities. Around 2012 it became clear that the industry was facing severe economic challenges. The situation was particularly dire in Germany, where wholesale power prices were reduced by more than 50\% from 2011 to 2016 (Newbery et al. 2017: 7-8). Over the years, Germany had added several compensation mechanisms to its support scheme, rendering the PreussenElektra ruling outdated. Hence, the German Association of Energy Consumers lodged a complaint with the Commission, arguing that the scheme now constituted state aid (CJEU 2016). The CJEU had also considered whether the French feed-in scheme constituted state aid and, in 2013, ruled that it did (CJEU 2013). This decision 
signified a shift in case law, and in late 2013 DG Competition initiated a formal investigation procedure with respect to the German scheme (CJEU 2016: 13).

By this stage, DG Competition was in the midst of a major 'modernization' of all state-aid practices, aimed at ensuring economic efficiency as well as legal certainty (Fitch-Roy et al. 2019: 85). DG Competition asked stakeholders to complete a questionnaire concerning revision of the state-aid guidelines relating to renewables. In their replies, the renewables industry called for minor alterations to ensure more effective implementation of the 2009 Renewables Directive, whereas the electricity industry declared itself generally satisfied with existing practices (Commission 2016). These inputs showed that few expected major changes in the new guidelines. However, according to interviewee 4: 'The member states had committed to the [renewables] targets, but it had consequences that few had expected. When the financial crisis came in addition, it was like a perfect storm'. DG Competition exploited this situation, and in 2013 it issued draft guidelines for consultation which proposed radically ramping up EU steering towards competitive tendering, combined with feed-in premiums. Interviewee 8 , who had been involved in promoting certificate schemes, stated: 'We lost that in 2008. . . I was okay with tendering. It was simply another way to ensure competition and costefficiency'. And Interviewee 3 highlighted how auctioning fit the thinking of the Commission in general and that the possibility for bidding processes had opened up in many areas of state aid.

As very few EU countries applied feed-in premiums combined with competitive auctions at this stage, the Commission's proposal came as a great surprise and gave rise to protests (Fitch-Roy et al. 2019). The CJEU ruling did not specify how support schemes should be designed; it merely pointed out that most schemes constituted state aid. The draft guidelines received considerable attention and many inputs. The seven largest utilities and the business association Eurelectric supported the Commission's new approach (Commission 2016). The renewables industry was more critical, arguing that the proposal conflicted with the Renewables Directive. Many interviewees, however, argued that the conflict over more, or less, market steering was not as prominent as before. DG Competition hailed the new UK and Dutch schemes as good models for national support schemes (Commission 2014).

Many member states, however, voiced scepticism. For instance, France, Germany, Poland, Sweden and the UK all called for greater leeway, arguing that the proposal was too restrictive (Commission 2016). Interviewee 3 mentioned the considerable member-state resistance at consultation meetings - a point confirmed by a letter from France, Germany, the UK and Italy in December 2013 (Bundesministerium für Wirtschaft und Energi 2016). The member states wanted leeway to continue with technology-specific feed-in to the extent they saw fit, and to avoid having to open up their schemes to renewables projects in other countries. The final 2014 guidelines were rather similar to the draft proposal, but included significant exemptions from the feed-in premium and auctioning requirement, allowing for more widespread use of technology-specific feed-in than the 2013 proposal (Community Guidelines 2014) 
Germany had changed its scheme towards feed-in premiums combined with auctioning already before the Commission concluded in 2014 that the scheme constituted state aid (CJEU 2016: 16). ${ }^{3}$ Interviewee 6 held that Germany would never have adjusted its scheme had it not been for Commission pressure, describing the meetings between DG Competition and Germany as 'really heated, really harsh' and 'they did all they could in this case'. Interviewee 5 expressed doubt as to whether the German government was really so displeased with the changes, commenting that 'the revision was in a way modelled on the German situation'. Several German actors had long fought against the feed-in scheme, and they became increasingly able to influence the many smaller revisions of the German support mix in this period. New pressure from the Commission increased the leverage of these actors even further (see Leiren and Reimer 2021, this book).

Interviewees $(2,6,8,9)$ mentioned considerable disagreements between the DGs over the new approach, and internal coordination seems to have been limited. Nonetheless, the College of Commissioners adopted the guidelines in April 2014. Several interviewees mentioned that the Commissioners cast formal votes, which was unusual.

The final 2014 guidelines differ radically from how renewables support was dealt with in prior guidelines and Renewables Directives. They prescribe that aid be 'granted in a competitive bidding process on the basis of clear, transparent and non-discriminatory criteria' (Article 3.3.2). Indeed, all new aid schemes are required to grant aid as a premium in addition to the electricity market price. The bidding process may be limited to specific technologies if certain conditions are met: if there is a 'need to achieve diversification', if the installed electricity capacity is very small, if the number of projects is limited or if competitive bidding could result in higher support levels. Such exemptions may be made only if they do not distort the electricity market or if the energy markets are so poorly designed that market-based support schemes would not work. The Commission has argued that during the period 2020-2030, established renewable energy sources will become grid-competitive, and subsidies should be phased out degressively (Article 3.2.4). The 2014 guidelines accept electricity certificate schemes as an alternative to auctioning and feed-in premiums.

In the immediate aftermath of the adoption of the new guidelines, many countries changed their support-scheme mixes. By the end of 2017, 18 out of $29 \mathrm{EU}$ and EEA countries (all EU member states except Slovakia, and Norway and Iceland in addition were assessed) had introduced tendering or were poised to do so (CEER 2018: 10). One year later, five EU member states (the Netherlands, Poland, Portugal, Spain and the UK) had implemented auctioning procedures with less technology-specificity, while France, Germany, Greece and Hungary planned to introduce more technology-neutral tenders over time.

Many countries adjusted their support-scheme mixes to the new guidelines, but there was also a surge of legal and political disputes relating to EU authority in relation to renewables support. In 2016, the CJEU ruled that German renewables support was indeed state aid, and thus all aspects relating to this would have to be designed in accordance with EU rules (CJEU 2016). Three years later, another 
chamber of the Court decided that the German scheme did not qualify as state aid after all, once again jeopardizing the authority of the EU over renewables support (CJEU 2019). On the other hand, renewables support gained attention in relation to a recast of the EU Renewables Directive, and as a result the new directive contained a long passage on this matter. Much of the language from the 2014 state-aid guidelines was copied into the new Directive (Directive 2018/2001). However, it should be noted that the text of the final directive included a long list of conditions that would allow the member states to 'limit tendering procedures', such as 'the need to achieve diversification' (Directive 2018/2001, Art 4.5). These criteria may obstruct the Commission in undertaking a more radical revision of the state-aid guidelines in the future. For instance, it may become difficult for the Commission to remove the exceptions that allow countries to retain technology-specific auctioning, and not shift to fully technology-neutral auctions.

Introduction of the 2014 state-aid guidelines serve to increase vertical Europeanization, providing DG Competition with far more authority over domestic support-scheme mixes than previously. A range of CJEU court cases accorded the Commission legitimacy to do so, and many years would pass before the CJEU made rulings that again created questions about the Commission's authority. Despite the legal and political battles, the EU had gained significant top-down power after 2014, and the EU governing was underpinned by a new trend towards auctioning combined with feed-in premium.

\section{Discussion and conclusions}

This chapter has described the Europeanization process relating to renewables support schemes, mapping how the state of the European environment changed significantly in the course of four decades, with respect to horizontal as well as vertical Europeanization aspects. From the 1970s until the late 1990s, there was relatively little Europeanization. Although the EU had passed some general policies, and there existed a general ban on state aid, it was not clear that any of this would influence the development of domestic support schemes. This was a 1000 flowers situation, with weak vertical and horizontal Europeanization. The few countries that did adopt renewables support schemes before 2000 chose differing models. Whether member states supported renewables, and how, depended largely on domestic initiatives and circumstances. While some EU actors, such as Commission officials, had ideas and clear opinions about how support schemes ought to be designed, these positions were not enshrined in EU law. EU member states, and later also the EEA countries, could generally do as they wished concerning support to renewables. As later chapters in this book show, Germany, UK, Poland, France, Sweden and Norway were to exploit this freedom in radically different ways.

We find greater coherence across EU member states after 2000. The years between 2000 and 2004 were a period of horizontal harmonization. Vertical Europeanization was weak; the EU adopted its first Renewables Directive, but this did not offer clear guidance as to renewables support. Moreover, the 2001 
PreussenElektra court case prevented the EU from applying Treaty rules on state aid to develop stronger vertical steering. The strong horizontal Europeanization process contributed primarily to the diffusion of feed-in schemes, although a few countries adopted electricity certificate schemes. As shown in the country studies in Part II of this book, Germany was a great inspiration for other countries in this period (UK, Poland and France); further, France and Poland were affected by the diffusion of feed-in, Norway and Sweden hardly at all.

Between 2005 and 2009, the horizontal harmonization continued, with the feed-in diffusion gaining speed and electricity certificate schemes becoming less popular. At the same time, the EU added binding domestic renewables targets to its revised Renewables Directive. Many member states ended up with targets that required them to do something to increase domestic renewables production, in turn creating pressure towards the adoption of more encompassing support schemes. Many actors saw this as underpinning more technology-specific schemes that would ensure that also more costly technologies were used, although the Directive did not require the member states to adopt such schemes. The vertical Europeanization of renewables support was fairly modest. More of our six case-study countries were affected, with Norway being the only one that did not introduce greater technology-specificity in its support-scheme mix in this period.

After 2010, the picture changed significantly, towards less technologyspecificity and stronger EU steering. By 2010, the CJEU had handed down several decisions legitimizing a more aggressive approach from DG Competition in renewable support cases (see Boasson 2019 for an assessment of Commission entrepreneurship in this respect). Moreover, many important countries, including France, Germany and the UK, had introduced or were in the process of introducing more competitive elements in their support schemes. This new support-scheme trend, or 'horizontal Europeanization', enabled the adoption of new state-aid rules that represented a radical increase in vertical Europeanization. Legal and political battles over the EU authority in this issue-area continued, but for many years after 2014, it appeared that the EU had gained new muscle in this issue-area, radically decreasing the leeway available to the member states. Hence we can say that this period was marked by EU governing.

\section{Interviewees}

1 Renewable industry representative, WindEurope (European business association for the wind-energy industry), 19 May 2016, Brussels

2 Civil servant, European Commission, DG Energy, 18 May 2016, Brussels

3 Civil servant, EFTA Surveillance Agency, 10 May 2016, Brussels

4 Electricity industry representative, Eurelectric (European business association for the electricity industry), 18 May 2016, Brussels

5 Civil servant, European Commission, DG Legal Service, 10 May 2016, Brussels

6 Cabinet-level civil servant, European Commission, DG Competition, 22 November 2016, Brussels 
7 Renewable industry representative, Eurosolar (European business association for the solar-energy industry), 22 November 2016, Brussels

8 Cabinet-level civil servant, European Commission, DG Climate Action, 23 November 2016, Brussels

9 Lower-level civil servant, European Commission, DG Competition, 23 November, Brussels

10 Renewable energy representative, European Renewable Energies Federation (EREF), 16 February 2017, Oslo

\section{Notes}

1 The titles of these DGs varied during the period covered by this chapter. For simplicity, they will be referred to as 'DG Competition and 'DG Energy'.

2 Much of the empirical material presented in the following was first published in Boasson (2019).

3 The CJEU confirmed this decision in 2016.

\section{References}

Banet, C. (2020) 'Legal status and legal effects of the Commission's state aid guidelines. The case of the guidelines on state aid for environmental protection and energy (EEAG) (2014-2020)', European State Aid Law Quarterly 19: 172-184.

Blauberger, M. (2009) 'Of 'good' and 'bad' subsidies: European state aid control through soft and hard law', West European Politics 32(4): 719-737.

Boasson, E.L. (2019) 'Constitutionalization and entrepreneurship: Explaining increased EU steering of renewables support schemes', Politics and Governance 7(1): 70-80.

Boasson, E.L. (2020) 'A dynamic multi-field approach', pp. 32-57 in E.L. Boasson, M.D. Leiren \& J. Wettestad (eds) (this book), Comparing Renewables Policy: The Role of Political, Organizational and European Fields. London: Routledge.

Boasson, E.L., H. Faber \& K. Bäckstrand (2021) 'Sweden: Electricity-certificate champion', ch. 9, pp. 171-192 in E.L. Boasson, M.D. Leiren \& J. Wettestad (eds) (this book), Comparing Renewables Policy: The Role of Political, Organizational and European Fields. London: Routledge.

Boasson, E.L., C. Banet \& J. Wettestad (2021) 'France: From renewables laggard to technology-specific devotee', pp. 149-169 in E.L. Boasson, M.D. Leiren \& J. Wettestad (eds) (this book), Comparing Renewables Policy: The Role of Political, Organizational and European Fields. London: Routledge.

Boasson, E.L. \& J. Wettestad (2013) EU Climate Policy: Industry, Policy Interaction and External Environment. Farnham: Ashgate.

Bundesministerium für Wirtschaft und Energie (2016) 'Undated letter', Retrieved from http://bmwi.de/BMWi/Redaktion/PDF/P-R/positionspapier-energie-und klimaleitlinien, property=pdf,bereich=bmwi2012, sprache=de,rwb=true.pdf, 15 May 2018.

Bürgin, A. (2015) 'National binding renewable energy targets for 2020, but not for 2030 anymore: Why the European Commission developed from a supporter to a brakeman', Journal of European Public Policy 22(5): 690-707.

Büthe, T. (2016) 'Historical institutionalism and institutional development in the EU: The development of supranational authority over government subsidies', pp. 37-67 in 
T. Rixen, L.A. Viola \& M. Zürn (eds), Historical Institutionalism \& International Relations. Oxford: Oxford University Press.

CEER (2018) Tendering Procedures for RES in Europe: State of Play and First Lessons Learnt. Council of European Energy Regulators. C17-SD-60-03. CEER: Brussels.

CJEU (2000) PreussenElektra: Opinion of Advocate General Jacobs delivered on 26 October 2000. Case 379/98. Luxembourg: Court of Justice of the European Union.

CJEU (2001) PreussenElektra: Judgement of the Court. Case 379/98. Luxembourg: Court of Justice of the European Union.

CJEU (2008) Opinion of Mr Advocate General Mengozzi delivered on 24 January 2008. Essent Netwerk Noord BV Case C-206/06. Luxembourg: Court of Justice of the European Union.

CJEU (2013) Judgement of the Court Association Vent De Colère! Case C-262/12. Request for a Preliminary Ruling Under Article 267 TFEU from the Conseil d'État (France). Luxembourg: Court of Justice of the European Union.

CJEU (2016) Judgment of the General Court of 10 May 2016: Germany v Commission (Case T-47/15) (1). Luxembourg: Court of Justice of the European Union.

CJEU (2019) Judgement of the Court (Third Chamber) 28 March 2019. APPEAL under Article 56 of the Statue of the Court of Justice of the European Union, in Case C-405/16. Luxembourg: Court of Justice of the European Union.

Cointe, B. \& A. Nadaï (2018) Feed-in Tariffs in the European Union: Renewable Energy Policy, the Internal Electricity Market and Economic Expertise. Cham: Palgrave Macmillan.

Commission (2008a) The Support of Electricity from Renewable Energy Sources (Commission staff working document, SEC 57). Brussels: European Commission.

Commission (2008b) Proposal for a Directive of the European Parliament and of the Council on the Promotion of the Use of Energy from Renewable Sources (COM (2008) 30 final/19 final, SEC 2008 57, SEC 2008 85, 23 January). Brussels: European Commission.

Commission (2014) Impact Assessment. Accompanying the Document Communication from the Commission Guidelines on State Aid for Environmental Protection and Energy for 2014-2020 (Commission staff working document, 139). Brussels: European Commission.

Commission (2016) 'State aid modernisation (SAM) and its implementation', European Commission', Retrieved from http://ec.europa.eu/competition/state_aid/modernisation/ index_en.html, 15 April 2018.

Community Guidelines (2001) 'Community guidelines on state aid for environmental protection', Official Journal of the European Communities (2001/C 37/03).

Community Guidelines (2008) 'Community guidelines on state aid for environmental protection', Official Journal of the European Union (2008/C 82/01).

Community Guidelines (2014) 'Community guidelines on state aid for environmental protection and energy 2014-2020', Official Journal of the European Union (2014/C 200/01).

Directive 2001/77/EC of the European Parliament and the Council on the Promotion of Electricity Produced from Renewable Energy Sources in the Internal Electricity Market. Brussels: European Commission. 


\section{Elin Lerum Boasson}

Directive 2018/2001 of the European Parliament and the Council of 11 December 2018 on the promotion of the use of energy from renewable sources (recast). Brussels: European Commission.

Fitch-Roy, O., D. Benson \& B. Woodman (2019) 'Policy instrument supply and demand: How the renewable electricity auction took over the world', Politics and Governance 7(1): 81-91.

Jacobsson, S. \& V. Lauber (2006) 'The politics and policy of energy system transformation: Explaining the German diffusion of renewable energy technology', Energy Policy 34(3): 256-276.

Kassim, H. \& B. Lyons (2013) 'The new political economy of state aid policy', Journal of Industry, Competition and Trade 13(1): 1-21.

Kuhn, T. (2001) 'Implications of the "Preussen Elektra" judgment of the European court of justice on the community rules on state aid and the free movement of goods', Legal Issues of Economic Integration 28(3): 361-376.

Leiren, M.D. \& I. Reimer (2021) 'Germany: From feed-in tariffs to greater competition', pp. 75-102 in E.L. Boasson, M.D. Leiren \& J. Wettestad (eds) (this book), Comparing Renewables Policy: The Role of Political, Organizational and European Fields. London: Routledge.

Mortensen, B.O.G. (2008) 'The European court of justice decision in case C-206/06, Essent Netwerk Noord BV', European Energy and Environmental Law Review 17: 389-393.

Newbery, D., M. Pollitt, R. Ritz \& W. Strielkowski (2017) Market design for a highrenewables European electricity system. EPRG Working Paper 1711. University of Cambridge Energy Policy Research Group.

Rayner, T., M.D. Leiren \& T.H. Inderberg (2021) 'The United Kingdom: From marketled policy towards technology steering', pp. 103-125 in E.L. Boasson, M.D. Leiren \& J. Wettestad (eds) (this book), Comparing Renewables Policy: The Role of Political, Organizational and European Fields. London: Routledge.

Rusche, T.M. (2015) EU Renewable Electricity Law and Policy. Cambridge: Cambridge University Press.

Smith, M.P. (1998) 'Autonomy by the rules: The European Commission and the development of state aid policy', Journal of Common Market Studies 36(1): 55-78.

Solorio, I. \& H. Jörgens (eds) (2017) A Guide to EU Renewable Energy Policy: Comparing Europeanization and Domestic Policy Change. Cheltenham: Edward Elgar. 